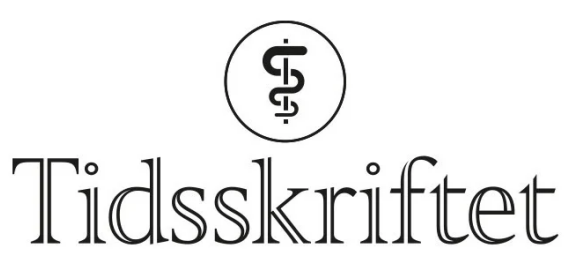

DEN NORSKE LEGEFORENING

\title{
Skrøpeligheit og befolkningsdata
}

\author{
KOMMENTAR
}

KRISTIN HESTMANN VINJERUI

kristin.vinjerui@ntnu.no

Kristin Hestmann Vinjerui er lege og ph.d.-stipendiat ved HUNT forskningssenter, Institutt for samfunnsmedisin og sykepleie, Norges teknisk-naturvitenskapelige universitet og seniorrådgiver ved Folkehelseinstituttet.

\section{HÅVARD KJESBU SKJELLEGRIND}

Ingen av forfatterne har oppgitt noen interessekonflikter.

Tidsskriftet nr. 4/2021 hadde fokus på eit generelt relevant tema, skrøpelegheit. Vi ønsker å supplere dei klinisk retta innlegga med data frå Helseundersøkinga i Trøndelag (HUNT). HUNT er ei av dei største befolkningsundersøkingane i Noreg, gjennomført kvart ti-år sidan 1984. HUNT4 inkluderte Trondheim og Sør-Trøndelag og vart avslutta i februar 2019. Til saman har over 240.000 trøndarar deltatt i HUNT-studiane og funn er generaliserbare til Noreg (1). Det er utfordrande å setje ei (kronologisk) aldersgrense for screening av skrøpelegheit, som er eit mål på biologisk alder. HUNT-data kan belyse dette, og målet med kommentaren er å oppmode klinikarar til å utforske dette rike materialet.

Dejgaard og Rostoft (ㅁ) trekte fram skrøpelegheit som eit mål på sårbarheit utover alder og multimorbiditet og Kyrdalen et al. (3) som eit fenomen òg blant yngre og med høgare førekomst i lågare sosioøkonomiske lag. Sosiale skilnadar i førekomst av å vera multimorbid og skrøpeleg i eit vidt alderspenn, er studert i data frå HUNT3 (2006 - 2008) (4). Totalt $39 \%$ av 25 til 100-åringar var multimorbide og samtidig skrøpelege, med fleire enn to kroniske tilstandar og meir enn ein nedsett funksjon (generell, psykisk, fysisk eller sosial). Sosioøkonomiske skilnadar i førekomst varierte med alder, men var til stades frå 30 år til over 80 år. Ved 70 års alder var førekomsten nær 60 \% l låg og 40 \% i høg sosioøkonomisk gruppe.

I HUNT3 var deltakinga låg hos dei over 80 år. Skeivheit mot friske deltakarar gjer estimata konservative. I HUNT4 var det ekstra tiltak for å auke eldre si deltaking, som heimebesøk og undersøking i institusjon. Deltakinga vart over 50 \% i alle 10-års aldersgrupper over 70 år. Prosjektet HUNT4 70+ omfattar blant anna skrøpelegheit (Frieds fenotype: gripestyrke, ganghastigheit, fysisk aktivitet, utmatting og ufrivillig vekttap), kognitiv og generell funksjon, tannhelse og ernæringsstatus hos over 11.0oo personar. Datamaterialet har vist at førekomsten av demens og mild kognitiv svikt er $14,6 \%$ og 35,2 \% hos dei over 70 år (5). Kyrdalen foreslår ei algoritme som skil mellom ganghastigheit $>1 \mathrm{~m} / \mathrm{s}, 0,8-1 \mathrm{~m} / \mathrm{s}$ og 
$<0,8 \mathrm{~m} / \mathrm{s}$. I våre data utgjer desse tre gruppene $46 \%, 28 \%$ og $26 \%$ av heimebuande over 70 år. Fram til omlag 75 år ligg 50-persentilen over $1 \mathrm{~m} / \mathrm{s}$, og fram til 85 år ligg 50-persentilen over o,8 m/s. Detaljerte oversiktar vil bli publisert i nær framtid.

Smådriftsfordelar i distrikta mogleggjer ofte godt samarbeid mellom fastlegar og kommunale tenester. Fastlegane sin kunnskap trengst ved utforming av mål og føringar for handsaming av pasientar med skrøpelegheit. Forskingsfinansiering rettast stadig meir mot forsking for og med kommunale tenester. Nasjonal forskerskole i allmennmedisin gir forskarutdanning og nettverk, sjølv om en ikkje held til på eit universitet. Vi ønsker å oppmode klinikarar i heile landet til å utforske idear og problemstillingar ved å nytte dei store befolkningsundersøkingane i Noreg.

\section{LITTERATUR}

1. Krokstad S, Langhammer A, Hveem Ket al. Cohort Profile: the HUNT Study, Norway. Int J Epidemiol 2013; 42: 968-77. [PubMed][CrossRef]

2. Dejgaard MS, Rostoft S. Systematisk vurdering av skrøpelighet. Tidsskr Nor Legeforen 2021; 141. doi: 10.4045/tidsskr.20.0944. [CrossRef]

3. Kyrdalen IL, Laukli I, Dunseth G et al. Fastlegens rolle ved skrøpelighet hos hjemmeboende eldre personer. Tidsskr Nor Legeforen 2021; 141. doi:10.4045/tidsskr.20.0582. [PubMed][CrossRef]

4. Vinjerui KH, Boeckxstaens P, Douglas KA et al. Prevalence of multimorbidity with frailty and associations with socioeconomic position in an adult population: findings from the cross-sectional HUNT Study in Norway. BMJ Open 2020; 10: e035070. [PubMed][CrossRef]

5. Gjøra L, Strand BH, Bergh S et al. Current and Future Prevalence Estimates of Mild Cognitive Impairment, Dementia, and Its Subtypes in a Population-Based Sample of People 7o Years and Older in Norway: The HUNT Study. J Alzheimers Dis 2021; 79: 1213-26. [PubMed][CrossRef]

Publisert:3. mai 2021. Tidsskr Nor Legeforen. DOI: 10.4045/tidsskr.21.0303

(C) Tidsskrift for Den norske legeforening 2023. Lastet ned fra tidsskriftet.no 26. april 2023. 